УДК 338.341

DOI: https://doi.org/10.37320/2415-3583/13.5

Гречан П.Ю.

аспірант,

Наиіональний транспортний університет

ORCID: https://orcid.org/0000-0003-4878-9744

\title{
ІННОВАЦІЙНА АКТИВНІСТЬ У СИСТЕМІ РОЗВИТКУ ПІДПРИЕМСТВА
}

Розвиток підприємства є об'єктивною необхідністю та метою функціонування кожного суб'єкта господарювання в умовах динамічного і мінливого зовнішнього середовища. У статті розкрито основні теоретичні аспекти інноваційної активності як підгрунтя всіх елементів системи управління розвитком. Визначено сутність інновачійної активності як узагальнюючої комплексної характеристики інтенсивності інноваційноі діяльності підприємства, яка здійснюється в межах інноваційного потенціалу $і$ спрямована на забезпечення довгострокового стійкого розвитку. Доведено, щзо інноваційний складник у вигляді продукту, технологї̈ або організаційної інновачії є обов 'язковим на всіх етапах управління підприємством і є інструментом досягнення економічного розвитку на конкурентному ринку. Виділено зовнішні та внутрішні фактори інноваційної активності, які впливають на формування конкретних домінант кожного підприємства та визначають можливі загрози ї̈ здійснення з урахуванням специфіки діяльності.

Ключові слова: інноваційна активність, розвиток підприємства, система управління розвитком підприємства, інноваційна діяльність, інноваційний потенціал, фактори інноваційної активності.

Постановка проблеми. Особливості діяльності підприємств в сучасних умовах характеризуються високою динамічністю і непередбачуваністю зовнішнього середовища, тенденціями глобалізації його чинників, що вимагає від суб'єктів господарювання постійного вдосконалення управління своїм розвитком. Для підвищення конкурентоспроможності та зміцнення ринкових позицій, на що спрямовуються дії, суб'єкти господарювання формують дієву систему розвитку, яка складається з важливих елементів (суб'єктів, об'єктів, принципів, методів, організаційних структур тощо), надзвичайно важливе місце в якій посідає інноваційний складник. Тому питання визначення місця значення інноваційної активності в системі розвитку підприємства $є$ надзвичайно важливим і актуальним завданням.

Аналіз останніх досліджень і публікацій. Категорія «інноваційна активність», враховуючи ії стратегічне значення у забезпеченні конкурентоспроможності, тривалий час знаходиться у полі уваги широкого кола вітчизняних і зарубіжних дослідників: І. Ансоффа, В.В. Стаднік, А.А. Малицького, О.С. Федоніна, Г.О. Швиданенко, H.I. Чухрай, М.А. Йохни та багатьох інших.

Незважаючи на значну кількість досліджень із різних питань теорії інноватики, кардинальні зміні у зовнішньому середовищі вимагають постійного розвитку теоретичних і методичних аспектів управління підприємствами, особливо у частині використання ними сучасних методів підвищення ефективності діяльності та забезпечення сталого економічного розвитку.

Метою статті $€$ визначення місця інноваційної активності в системі управління розвитком підприємства та виділення факторів впливу на підвищення ефективності їі застосування.

Виклад основного матеріалу дослідження. У сучасній літературі у сфері дослідження проблем розвитку підприємства науковці і практики переважно акцентують увагу на багатоаспектності цього питання $[1 ; 2 ; 5 ; 8 ; 12 ; 13]$. Натомість, узагальнюючи висновки вчених щодо поняття «розвиток», можна визначити певні властивості цього економічного процесу: під роз- витком розуміють збільшення масштабів і складності явища; поліпшення адаптованості до зовнішніх умов; кількісний ріст економічних параметрів і якісне поліпшення їх структури; соціальний прогрес та ін. Отже, розвиток будь-якого явища характеризується динамічністю якісних змін, тобто переходом від одного стану до іншого, необоротністю розвитку, а головне - це є складним багатоаспектним процесом, реалізація якого передбачає функціонування складної комплексної системи.

Погоджуючись 3 А.О. Устенко [14, с. 103], необхідно відзначити, що «це комплекс, який включає цільову, забезпечувальну, функціональну, керуючу, керовану, науково-методичну та зовнішню підсистеми, що сприяють ухваленню та реалізації конкурентоспроможних управлінських рішень, спрямованих на задоволення заданої ринкової потреби; це комплексна система забезпечення конкурентоспроможності підприємства в конкурентному середовищі». Такий підхід повністю відповідає економічному закону розвитку, відповідно до якого кожна система в процесі свого розвитку прагне оптимальної самореалізації як цілого, так і складових своїх елементів на основі їхньої активності та динамічної рівноваги [4, с. 103].

Вивчення підходів науковців щодо виділення складових частин системи управління розвитком підприємства дає змогу констатувати багатоваріантність їх сукупності і відсутність єдиного підходу.

Так, В. Харченко узагальнено виділяє підсистеми управління, керовані елементи підсистем управління та зовнішні фактори впливу на управлінські рішення $[15$, с. 99], в роботі Н. Калюжної елементами системи управління є: функції управління, організаційна структура управління, персонал управління, управлінська інформація, технічні засоби управління, методи управління, технологія управління та управлінські рішення [9, с. 137].

В основному погоджуючись із пропозиціями авторів, вважаємо за необхідне наголосити на важливості інноваційного підгрунтя в кожному із виділених елементів. Забезпечення економічного зростання потребує прискореного розвитку високотехнологічного виробництва, спроможного виробляти сучасну науко- 
ємну продукцію, прийняття ефективних управлінських рішень неможливе без застосування організаційних інновацій, отже, підвищення технологічного рівня підприємств, формування їхніх конкурентних переваг відбувається завдяки прогресивним вітчизняним і світовим науково-технічним досягненням. Потреба сьогодення в нових теоретичних і практичних підходах до управління розвитком на інноваційній основі, а також формування і розвиток продуктової, організаційної та технологічної конкурентоспроможності підприємств посилили вагомість і визначили необхідність підвищення інноваційної активності для досягнення стратегічних цілей кожним суб'єктом господарювання.

Тому вважаємо дискусійними висновки С.П. Дунди, що основні шляхи розвитку підприємств - саморозвиток, трансформація, реструктуризація, інноваційний розвиток [6]. Застосування інноваційної складової частини як окремого варіанту розвитку не сприяє впровадженню сучасних знань і надбань технічного прогресу, новітніх організаційних, інформаційних, управлінських технологій на всіх управлінських ланках. Тільки постійне і всеохоплююче використання в управлінні підприємством інноваційних підходів і моделей дає змогу досягти стратегічних цілей внаслідок формування ключових компетенцій, конкурентних переваг.

Проблеми визначення сутності категорії «інноваційна активність» багатоаспектно порушували українські науковці у своїх роботах, але за сучасних умов немає єдиного підходу до визначення іiї позиції в системі управління розвитком підприємства.

Безумовно, основними базисами інноваційної активності $\epsilon$ інноваційна діяльність і інноваційний потенціал підприємства. Згідно із чинним законодавством, інноваційна діяльність визначається як діяльність, що спрямована на використання, комерціалізацію результатів наукових досліджень та розробок і зумовлює випуск на ринок нових конкурентноздатних товарів і послуг [7]. Але наявність на підприємстві інноваційної діяльності ще не характеризує ії ефективність і напруженість.

Як зазначає В.Ю. Вострякова, поєднання ресурсів, можливостей та компетенцій в інноваційній діяльності характеризує інноваційний потенціал [3, с. 64]. Він створює той діапазон можливостей, які доступні для застосування підприємством для розроблення (або придбання) та здійснення інноваційної діяльності, спрямованої на суттєве поліпшення усіх аспектів господарсько-економічної системи.

Симбіозом інноваційної діяльності та інноваційного потенціалу і є інноваційна активність, яка $є$ узагальнюючою комплексною характеристикою інтенсивності інноваційної діяльності підприємства, що заснована на здатності до мобілізації інноваційного потенціалу і спрямована на отримання позитивного результату, що відобразиться у їхньому довгостроковому стійкому розвитку (рис. 1).

Отже, необхідно передбачити ідентифікацію стану інноваційної активності на всіх ланках системи управління розвитком підприємства в напрямі надання їй певної позитивної спрямованості: необхідно виокремити такі домінанти інноваційної активності кожного елемента, які зможуть підсумувати та накопичити позитивні імпульси інноваційної складової частини, одночасно пригнічуючи загрози та ризики.

Індикатори інноваційної активності показують ефективність функціонування та характеризують стан і тенденції в інноваційній діяльності підприємства, відображають їхню дію у забезпеченні системи управління сучасними методами й інструментами, спрямованими на формування і поглиблення конкурентних переваг у напрямі розвитку підприємства.

Проте обов'язковою складовою частиною ідентифікації встановлення рівня інноваційної активності $€$ не тільки фіксація переліку індикаторів, а й обгрунтування їхніх граничних значень. Вони є індивідуальними для кожного підприємства, саме оптимальні межі можуть сприяти найкращому із можливих варіантів досягнення інноваційної активності на кожній ланці системи управління підприємством. Наближення показників інноваційної активності підприємства до оптимальних свідчитиме про те, що вона повністю забезпечує реалізацію поставлених стратегічних завдань. Але якщо індикатори наближаються до граничних меж, то така ситуація свідчить про наростання впливу загроз та небезпек для підприємства, що вимагає прийняття невідкладних кардинальних управлінських рішень з їх усунення.

Враховуючи те, що інноваційна активність підприємства є підгрунтям системи управління розвитком підприємства, що охоплює всі їі складники, величезного значення набуває виділення факторів впливу на неї.

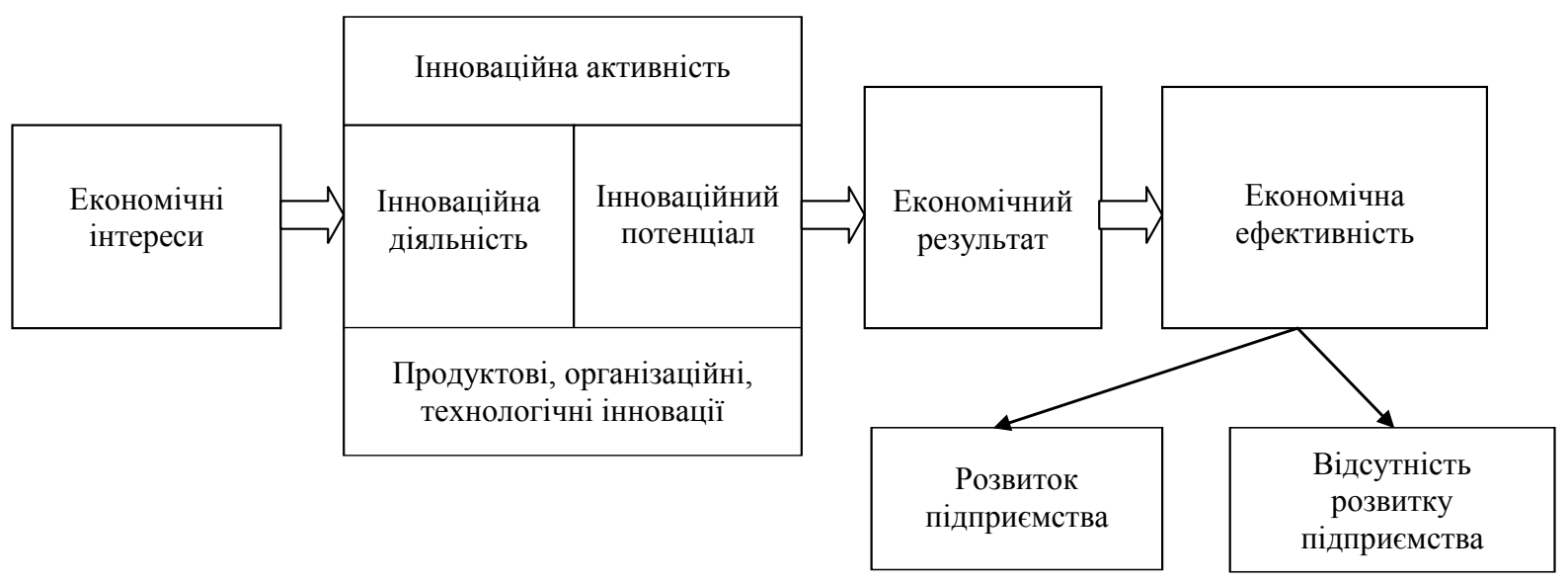

Рисунок 1 - Вплив інноваційної активності на розвиток підприсмства 
Загальноприйнятим є розподіл впливу факторів на економічні системи з виділенням зовнішніх та внутрішніх.

Враховуючи особливості категорії «інноваційна активність», до внутрішніх факторів доцільно віднести такі, як: організаційна структура управління, організаційна культура, наявні і доступні ресурси для здійснення інноваційної діяльності (нематеріальні, фінансові, трудові, матеріальні, інформаційні), система стимулювання на підприємстві.

Внутрішні фактори створюють передумови ефективного розвитку на інноваційній основі та спираються на внутрішній потенціал підприємства як економічної системи. Фактори зовнішнього середовища відіграють надзвичайно важливу роль для спонукання (або стримання) і водночас забезпечення підприємства, щоб активно впроваджувати інноваційну компоненту у всі сфери управління та діяльності. Узагальнено можна виділити чотири групи факторів зовнішнього середовища, які, у свою чергу, деталізуються конкретними напрямами:

- міжнародні (міжнародна політика держави, міжнародна конкуренція, загальноекономічні міжнародні фактори);

- національні (політичні, економічні, соціальні);

- регіонально-галузеві (розвиненість території та вигідність географічного положення, галузева структура регіону, рівень пріоритетності та розвиненість галузі, стан взаємодії суб'єктів господарювання на ринку товарів і послуг);

- комерційні (науково-технічні, психографічні, ринкові).

Кожний із виділених факторів може слугувати як драйвером, так і стримувачем інноваційної активності. Тому кожне підприємство, враховуючи свої унікальні особливості і специфіку діяльності, повинно безперервно відстежувати зміни у визначених для себе пріоритетних факторах і забезпечувати гнучку й оперативну адаптацію (трансформацію) елементів системи управління розвитком до нових завдань, нової ситуації з використанням інноваційних інструментів і підходів.

Висновки. Прискорення трансформацій у навколишньому середовищі, поява нових потреб і змін позицій споживача, загострення конкуренції за товари і ресурси, глобалізація бізнесу, поява нових можливостей для здійснення бізнесу, розвиток інформаційних мереж, широка доступність сучасних технологій, зміна ролі людських ресурсів, а також низка інших чинників привели до різкого зростання значення управління розвитком підприємств. Теоретичним підгрунтям та дієвим інструментом ефективного функціонування кожного елемента системи управління розвитком підприємства $€$ інноваційна активність, яка не лише сприяє реалізації потенційних можливостей, але й дає змогу сформувати нові конкурентні переваги шляхом застосування технологічних, організаційних та продуктових інновацій.

\section{Список використаних джерел:}

1. Ансофф И. Стратегическое управление [пер. с англ.]. Москва : Экономика, 2005. 303 с.

2. Богацька Н.М., Кохан А.В., Майданюк Я.Л. Умови розвитку підприємства в сучасному ринковому середовищі. Економіка, 2010. № 10. URL: http://www.rusnauka.com/2 ANR 2010/Economics/10 53371.doc.htm (дата 3вернення: 03.07.2020).

3. Вострякова В.Ю. Динамічна модель інноваційного потенціалу підприємства. Вісник ОНУ ім. I.I. Мечникова, т. 20, вип. 2/2. 2015. С. 61-65.

4. Гончарова Н.П., Федонін О.С., Швиданенко Г.О. Управління підприємствами: сучасні тенденції розвитку : монографія та ін. Київ : КНЕУ, 2006. 288 с.

5. Дакус А.В., Сімченко Н.О. Економічний розвиток підприємства: сутність та визначення. URL: http://probl-economy.kpi.ua/ pdf/2012-3.pdf (дата звернення: 03.07.2020).

6. Дунда С. П. Розвиток підприємства та оцінка факторів, що на нього впливають. Ефективна економіка № $12,2016$. URL: http://www.economy.nayka.com.ua/?op=1\&z=5329 (дата звернення: 30.06.2020).

7. Закон України "Про інноваційну діяльність" від 4 липня 2002 р. № 40-IV. Відомості Верховної Ради України. 2002. № 14. С. 177-182.

8. Залуцький В.П. Сутність соціально-економічного розвитку машинобудівних підприємств: методи та принципи їх забезпечення. Науковий вісник НЛТУ України. 2009. Вип. 19.11. С. 163-169.

9. Калюжна Н. Визначення елементного складу системи управління підприємством як передумова дослідження іï потенціалу. Економічний аналіз. 2012. Т. 10(4). С. 135-138. URL: http://nbuv.gov.ua/UJRN/ecan_2012_10\%284\%29_32 (дата звернення: 07.07.2020).

10. Касьянова Н.В. Управління розвитком підприємства на основі кумулятивного підходу: концепція, моделі та методи : моногр. Донецьк : СПД Купріянов В.С., 2011. 374 с.

11. Кривов'язюк І.В. Сутність та класифікаційні підходи до видової характеристики стратегічних можливостей підприємства. Економічний форум. № 4. 2016. С. 150-157.

12. Малицький А.А. Організаційно-економічний механізм управління підприємством. URL: http://intkonf.org/malitskiy (дата звернення: 07.07.2020).

13. Рябуха Г.І. Фактори ефективності діяльності підприємств галузі тваринництва у ринковому середовищі. Формування ринкових відносин в Україні, 2016. № 6. С. 84-88.

14. Устенко А.О. Система управління підприємством. Вісник Прикарпатського університету. Економіка. 2014. Випуск Х. C. $96-103$.

15. Харченко В.А. Механізм формування системи стратегічного управління розвитком промислового підприємства. URL: http://www.econindustry.org/arhiv/html/2014/10-68.pdf (дата звернення: 09.07.2020).

\section{References:}

1. Ansoff I. (2005). Strategicheskoye upravleniye [Strategic management]. [per. s angl.]. Moskva: Ekonomika, 303 p.

2. Bohats'ka N.M., Kokhan A.V., Maydanyuk Y.L. (2010). Umovy rozvytku pidpryyemstva v suchasnomu rynkovomu seredovyshchi [Conditions of enterprise development in the modern market environment]. Ekonomika, № 10. URL: http://www.rusnauka.com/2_ANR_2010/Economics/10_53371.doc.htm (accessed 03 July 2020). (in Ukrainian)

3. Vostryakova V.Y. (2015). Dynamichna model' innovatsiynoho potentsialu pidpryyemstva [Dynamic model of innovative potential of the enterprise]. Visnyk ONU im. I.I. Mechnykova, t. 20, vyp. 2/2.2015, pp. 61-65. (in Ukrainian) 
4. Honcharova N.P., Fedonin O.S., Shvydanenko H.O. (2006). Upravlinnya pidpryyemstvamy: suchasni tendentsiyi rozvytku: monohrafiya [Enterprise management: current trends: monograph]. Kyiv: KNEU, 2006. 288 p. (in Ukrainian)

5. Dakus A.V., Simchenko N.O. Ekonomichnyy rozvytok pidpryyemstva: sutnist' ta vyznachennya [Economic development of the enterprise: essence and definition]. URL: http://probl-economy.kpi.ua/pdf/2012-3.pdf (accessed 03 July 2020). (in Ukrainian)

6. Dunda S.P. (2016). Rozvytok pidpryyemstva ta otsinka faktoriv, shcho na n'oho vplyvayut'. [Development of the enterprise and assessment of the factors influencing it]. Efektyvna ekonomika, № 12. URL: http://www.economy.nayka.com.ua/?op=1\&z=5329 (accessed 30 June 2020). (in Ukrainian)

7. Zakon Ukrayiny "Pro innovatsiynu diyal'nist"" [On Innovation Activity] vid 4 lypnya 2002 r. № 40-IV. Vidomosti Verkhovnoyi Rady Ukrayiny. 2002. № 14. pp. 177-182. (in Ukrainian)

8. Zaluts'kyy V.P. (2009). Sutnist' sotsial'no-ekonomichnoho rozvytku mashynobudivnykh pidpryyemstv: metody ta pryntsypy yikh zabezpechennya [The essence of socio-economic development of machine-building enterprises: methods and principles of their provision]. Naukovyy visnyk NLTU Ukrayiny. Vyp. 19.11, pp. 163-169. (in Ukrainian)

9. Kalyuzhna N. Vyznachennya elementnoho skladu systemy upravlinnya pidpryyemstvom yak peredumova doslidzhennya yiyi potentsialu [Determining the elemental composition of the enterprise management system as a prerequisite for the study of its potential]. URL: http://nbuv.gov.ua/UJRN/ecan_2012_10\%284\%29_32 (accessed 07 July 2020). (in Ukrainian)

10. Kas'yanova N.V. (2011). Upravlinnya rozvytkom pidpryyemstva na osnovi kumulyatyvnoho pidkhodu: kontseptsiya, modeli ta metody: monohr. [Enterprise development management based on a cumulative approach: concept, models and methods]. Donets'k: SPD Kupriyanov V.S., 374 p. (in Ukrainian)

11. Kryvov"yazyuk I.V. (2016). Sutnist' ta klasyfikatsiyni pidkhody do vydovoyi kharakterystyky stratehichnykh mozhlyvostey pidpryyemstva [The essence and classification approaches to the species characteristics of the strategic capabilities of the enterprise]. Ekonomichnyy forum, № 4, pp. 150-157. (in Ukrainian)

12. Malyts'kyy A.A. Orhanizatsiyno-ekonomichnyy mekhanizm upravlinnya pidpryyemstvom [Organizational and economic mechanism of enterprise management]. URL: http://intkonf.org/malitskiy (accessed 07 July 2020). (in Ukrainian)

13. Ryabukha H.I. (2016). Faktory efektyvnosti diyal'nosti pidpryyemstv haluzi tvarynnytstva u rynkovomu seredovyshchi [Factors of efficiency of activity of the enterprises of branch of animal husbandry in the market environment]. Formuvannya rynkovykh vidnosyn v Ukrayini, 2016, № 6, p. 84-88. (in Ukrainian)

14. Ustenko A.O. (2014). Systema upravlinnya pidpryyemstvom [Enterprise management system]. Visnyk Prykarpats'koho universytetu. Ekonomika. Vypusk X, pp. 96-103. (in Ukrainian)

15. Kharchenko V.A. Mekhanizm formuvannya systemy stratehichnoho upravlinnya rozvytkom promyslovoho pidpryyemstva [The mechanism of formation of the system of strategic management of industrial enterprise development]. URL: http://www.econindustry.org/ arhiv/html/2014/10-68.pdf (accessed 09 July 2020). (in Ukrainian)

Grechan Pavlo

National Transport University

\section{INNOVATIVE ACTIVITY IN THE ENTERPRISE DEVELOPMENT SYSTEM}

The article is devoted to substantiation of scientific and theoretical approaches to determining the role of innovative activity of the enterprise in the management system of its development in the conditions of increasing competition and market globalization.

The object of research is a scientific and theoretical basis for determining the essence of innovative activity of the enterprise and identifying its place in the management system of economic development of the business entity.

The purpose of the work is to generalize the economic content and substantiate the importance of innovation activity to ensure effective management of economic development of the enterprise.

The research method is a systematic theoretical substantiation of the relationship between innovation processes in the enterprise and its economic development.

Under modern conditions, the requirements for increasing the level of their competitiveness in the market are becoming more and more strict for business entities, which objectively requires constant improvement of the system of management of their development. The article proposes a new approach to determining the role of innovation in ensuring the economic growth of the enterprise. It is substantiated that the innovation component is the basis for the functioning of all elements of the enterprise development management system. Innovative activity is a generalized complex characteristic of the symbiosis of innovative activity and innovative potential. It is an integral part of achieving a positive result, which will be reflected in long-term sustainable development. The application of product, technological, organizational innovations in management is a modern tool to improve the market position of the enterprise in a competitive market in a dynamic environment. Much attention is paid to identifying the factors of internal and external environment that affect innovation in the enterprise. Taking them into account helps to increase the efficiency of management in the enterprise, develop its competitive advantages and ensure sustainable economic development.

Key words: innovation activity, enterprise development, enterprise development management system, innovation activity, innovation potential, factors of innovation activity.

JEL classification: D24, D25 